\title{
ほ場整備事業における生物多様性保全のための環境配慮工法の変遷と課題 -石川県の事例-
}

\author{
草光紀子 ${ }^{1} \cdot$ 一恩英二 ${ }^{2} \cdot$ 上田哲行 ${ }^{3}$
}

\section{Changes and Challenges of Environment-conscious Construction Methods for the Conservation of Biodiversity in Land Consolidation Projects}

\author{
-A Case Study in Ishikawa, Japan -
}

\author{
Noriko Kusamitsu ${ }^{1}$, Eiji Ichion ${ }^{2}$ and Tetsuyuki Uéda ${ }^{3}$
}

\begin{abstract}
The change of environment-conscious construction methods in land consolidation projects was investigated on the case of Ishikawa, Japan. The results showed that (1) the installation of environment-conscious facilities in Ishikawa began just after the notice of land improvement projects by the Japanese government in 1991, (2) the rate of land consolidation projects which included environment-conscious facilities reached $80 \%$ already when the revised Land Improvement Act was enforced, and has become 100\% recently, (3) in each project the number of the kinds of environment-conscious construction methods and targeted conservation species has been increasing, (4) recent land consolidation projects had a tendency to select oriental weather loach and frogs for targeted conservation species, and (5) overusing of concrete products for environment-conscious facilities has become prominent. It was inferred that the recent trend of overusing concrete products has been caused by the regard to the local residents forced to the burden of the maintenance of the facilities, and besides by the prefectural government policy that concentrates to the conservation of particular species. We considered that it is necessary to change the consciousness of local residents against coexisting plants and animals, in cooperation with an environmental education, to achieve more effective facilities for conservation of biodiversity.
\end{abstract}

Keywords: environment-conscious construction methods; land consolidation projects; biodiversity conservation; environment-conscious canals; biotope; targeted conservation species

1 はじめに

高度経済成長下の1960年代以降, 農業・農村構造の変化 や農業技術の近代化により, 生産性や農業者の生活は格 段に向上した (中川, 2001). その一方で, 農村環境に生 息する生物は急激な変化に対応できず, 生物多様性の低 下が危惧される事態になっている(江崎・田中, 1998; 鷲谷, 2006）。たとえば, 石川県の絶滅のお之れのある野生生物 864 種のうち約3 分の 2 が里山や里地に生息する生物であ ると言われている(石川県環境安全部, 2001)。このような 事態に対して, 農林水産省でも, 生物多様性を保全する ための様々な施策が打ち出されている.

農村環境の生物多様性の保全において転換点となった のは, 1991年に出された農林水産省構造改善局建設部 長通達「農村環境に配慮した土地改良事業の実施につい て」(以下「国通達」)である.この通達により, 環境に配慮 する工夫が促され，取り組みが徐々に広がった（岩村, 2001）。1992年には国連地球環境サミットが開催され, 生

1石川県立大学大学院生物資源環境学研究科博士課程 Ph.D. Student, Graduate School of Bioresources and Environmental Sciences, Ishikawa Prefectural Univerisity, 1-308 Suematsu, Nonoichi, Ishikawa 921-8836, Japan

2 石川県立大学生物資源環境学部准教授, Associate Professor, Faculty of Bioresources and Environmental Sciences, Ishikawa Prefectural Univerisity, 1-308 Suematsu, Nonoichi, Ishikawa 921-8836, Japan

石川県立大学生物資源環境学部教授, Professor, Faculty of Bioresources and Environmental Sciences, Ishikawa Prefectural Univerisity, 1-308 Suematsu, Nonoichi Ishikawa 921-8836, Japan
物多様性条約が採択されている. 1999年には農業農村の 持つ多面的機能の発揮を大きな $1 つ の$ 柱とした食料・農 業・農村基本法が制定され, 環境亡の調和への配慮 (以下 「環境配慮」) が原則化された。 それを受けて2001年に土 地改良法が一部改正され (以下「改正法」), 農業農村整 備事業の実施における環境配慮が義務づけられている. そして2002年度から農業農村整備事業等基本要綱に基 づき環境配慮が実施されている. 2007年には農林水産省 生物多様性戦略が策定され, 生物多様性保全を重視した 農林水産業を推進するための指針も示されている.

土地改良法で対象とされている農業農村整備事業には, 灌溉排水やほ場整備, 農道などの農業生産基盤の整備・ 保全に係わる事業, 農村振興や中山間地域の整備に係 わる農村整備事業などがあるが, 特に, ほ場整備は, 現況 の環境を陸域, 水域にわたって面的に大幅に改変するた め, 環境への影響が大きい. ほ場整備に伴う区画拡大や 乾田化, 水路のコンクリート化などによって, 生物の生息空 間の峦失や悪化, 生物の移動経路の分断をもたらすこと が指摘されている(江崎・田中, 1998; 中川, 2000; 2001; 森ら, 2008). これらの問題点に対して, 様々な対策工法 が研究開発され, 現場でも実施されている(水谷, 2007な ど).

本研究では, 特にほ場整備に焦点を当て, 環境配慮に 係わる法の整備や国による事業制度が自治体の中でごの ように方向づけられ, 現場で展開されるようになったか, そ の経緯と取り組み内容の変遷について, 石川県のほ場整 
備事業を事例として分析する. その際に, 上述した問題点 に対して, 石川県ではどのような対策工法がとられている のか, その内容はどう変化してきたのか, その変化の理由 は何かを分析し, 分析結果を踏まえて, 生態系保全とりわ け生物多様性の保全に向けた環境配慮事業における今 後の課題を検討する.

\section{2 石川県における環境配慮施策の展開の概要}

環境配慮に関する石川県と国の主要な施策等を年表形 式で表 1 にまとめた。

石川県の農業農村整備における生物多様性保全に向 けた取り組みは, 国通達直後の1991年度に排水特別対策 事業で魚巣ブロックが設置された事業が最初である. その 後, 水環境整備事業, 広域自然環境整備事業, 生態系保 全型水田整備推進事業など, 水質保全, 親水, 景観や生 態系保全といった時代ごとのニーズに応じて創設, 拡充さ れてきた国の事業制度(棚木ら, 2004)を利用した対応が なされている. また県の教育委員会や環境部と連携して, 2000年度から県独自の事業として「いしかわ森と田んぼの 学校推進プロジェクト」が開始され, 農村のもつ多面的機 能について体験を通して学ぶことで, 子ども達の豊かな感 性を育てる活動が農林水産部主導で実施されてきている。 2001年度には県職員提案による県単独事業「田んぼのま なび舎設置事業」が実施され, ほ場整備事業の中で体験 型教育空間としてのビオトープが設置されている(奥池, 2002).このように, 県農林行政の中では, 改正法が施行 される以前から生物多様性保全に関する取り組みが実施 されていた。特に, 県独自の環境教育と連携した取り組み
がなされていたことは注目される.

2001年6月の土地改良法の一部改正の公布を受けて, 他の都道府県と同様, 石川県においても環境配慮に係る 情報協議会に相当する石川県農業農村整備事業環境配 慮検討会 (以下「県検討会」)が2002年度に設置され，専 門的見地から環境配慮について検討されることとなった。

2004年1月には，「いしかわほ場整備環境配慮指針(以 下「県指針」)」(石川県, 2004a)が，有識者を交えた 3 年間 の検討と事例研究を踏まえて制定された. 県指針の中で は, ほ場整備事業担当者が行うべき必須事項として, 生物 調査の実施や事業への住民参加の促進等が示され, 現 場条件に合わせて配慮する優先配慮事項も定められた。 一方, 県指針制定以前には, 農林水産省により2001年度 から2003年度にかけて環境配慮の具体化に向けた「環境 との調和に配慮した事業実施のための調査計画・設計の 手引き」3 編(農林水産省農村振興局事業計画課, 2004a; 2004b；2004c)（以下「国手引き1〜3」)が作成されており， 県指針後の 2007 年には「生態系配慮の技術指針 (以下 「国指針」)」(農林水産省農村振興局事業計画課, 2007) が作成されている. 県指針は, これらの国手引き1〜3や国 指針ではほとんど触れられていない環境教育との連携の 重要性が強調して示されているところに特徴がある.さうに, 県指針には, 調査, 計画, 設計, 施工, 事後モニタリング に至るまでの考え方や重要なポイントを示した本文だけで なく, 全国の事例を集めた参考事例集, さらに地域住民と 一体となった取り組みとするための指針副読本も添付され ており, 合計269頁にも及ぶ大部の冊子として現場担当者 に提供されている.

表 1：環境配慮に関する石川県と国の主な施策

\begin{tabular}{|c|c|c|}
\hline 年月 & 石川県の主な施策 & 国の主な施策 \\
\hline 1965 年 & •県営ほ場整備事業開始 & \\
\hline 1991 年 8 月 & & $\begin{array}{l}\text { •「農村環境に配慮した土地改良事業の実 } \\
\text { 施について」(国通達) }\end{array}$ \\
\hline 2000 年 3 月 & $\begin{array}{l}\text { •「石川県の絶滅のおそれのある野生生物 (動物編, 植物 } \\
\text { 編)」作成 (RDB) }\end{array}$ & \\
\hline 2000 年 & •「いしかわ森と田んぼの学校推進プロジェクト」開始 & \\
\hline 2001 年 6 月 & & $\begin{array}{l}\text { •土地改良法の一部を改正する法律 (改正 } \\
\text { 法)公布(施行は } 2002 \text { 年) }\end{array}$ \\
\hline 2002 年 2 月 & & $\begin{array}{l}\text { •「環境との調和に配慮した事業実施のた } \\
\text { めの調査計画・設計の手引き } 1 」 の \text { 報告 } \\
\text { (発行は } 2004 \text { 年) (国手引き) }\end{array}$ \\
\hline 2002 年 4 月 & •県農業農村整備事業環境配慮検討会発足（県検討会） & \\
\hline 2004 年 1 月 & •いしかわほ場整備環境配慮指針制定（県指針） & \\
\hline 2004 年 3 月 & •ふるさと石川の環境を守り育てる条例制定 & \\
\hline 2005 年 6 月 & •各事務所に環境配慮情報協議会発足 (協議会) & \\
\hline 2007 年 2 月 & & •「生態系配慮の技術指針」制定 (国指針) \\
\hline 2007 年 7 月 & & •農林水産省生物多様性戦略策定 \\
\hline 2009 年 3 月 & •「石川県の絶滅のおそれのある野生生物 (動物編)」改訂 & \\
\hline 2009 年 & •農地整備環境機能増進事業実施(～2010)(増進事業) & \\
\hline 2010 年 3 月 & •「石川県の絶滅のおそれのある野生生物 (植物編)」改訂 & \\
\hline 2011 年 3 月 & $\begin{array}{l}\text { •石川県生物多様性戦略ビジョン策定 (県多様性ビジョン) } \\
\text { ・パンフレット「しかわ䭪整備における環境配慮の取り } \\
\text { 組み」作成(県パンフ) }\end{array}$ & \\
\hline 2011 年 4 月 & $\begin{array}{l}\text { ・「ほ場整備等における水路整備の申し合わせ事項 (内 } \\
\text { 規)」(県内規) }\end{array}$ & \\
\hline 2011 年 6 月 & •能登半島が世界農業遺産に認定 & \\
\hline
\end{tabular}


2005年度には, 県検討会で検討すべき年間事業件数 が多過ぎることと, 各地域の環境の実情に詳しい専門家に よる検討を行った方が良いといら判断から, 県内に5箇所あ る農林総合事務所ごとに農業農村整備事業環境配慮情 報協議会 (以下「協議会」) が設置され, その 1 年後に県検 討会は廃止された. 協議会発足後は, すべての事業につ いて, 協議会委員と地域住民等が参加する生物調査を実 施した上で, 環境配慮計画が作成されている.また, 一部 の事業では, 特別に個別の検討会を設置し, 専門的環境 調査や配慮の検討が行われる場合もあつた。

2009年度からは，国の水田環境向上基盤整備支援事 業の制度を利用し, 県指針を見直すこと等を目的とした農 地整備環境機能増進事業(以下「増進事業」)が2年間に わたり実施された。増進事業では，モデル地区を設けて， 現況調査 (40地区), 環境配慮施設の事後検証・評価 $(20$ 地区) が実施され, 有識者による検討会で生物多様性保 全の観点での環境配慮施設の改良対策が検討された. そ の結果を基に, 8地区で施設の改良が実施された. 増進事 業の検討結果を踏まえて2011年3月には, 農業農村整備 に係わる技術者やほ場整備を予定している地域住民を対 象に, 環境配慮の意義や施設設置方法などを紹介したパ ンフレット「いしかわのほ場整備における環境配慮の取り 組み(以下「県パンフ」)」(石川県農林水産部農業基盤課, 2011) が作成された。 県パンフでは, わかりやすい目標設 定としての保全対象種設定の必要性や選定方法, 地域の 生物を継続的に地域住民が調査する必要性等が示され ている. 特に, 水路整備に際しては, 全国の事例を紹介し た県指針の事例集とは違い, 県内の事例を数多く示しな がら具体的な工法や効果を示している. 特に「淀み」,「深 み」,「泥溜め」について大きく取り上げていることに特徵が ある. さらには, 江 (水田内承水路)の設置やV溝直播によ る夏期湛水など，営農時の工夫にまで踏夕込んで, 生物 多様性を保全するための取り組みを紹介している。また， 新規のほ場整備事業については, 事業採択後 1 年目にコ ンサルタント会社による専門的生物調査を実施することが 明記されており, その結果, コンサルタント会社による調査 の実施率は，今回集計したところ県指針制定前年までは 6\%, 県指針制定後から増進事業前年までは25\%であった ものが，増進事業後の2年間では100\%となっていた。

2011年4月には, 増進事業の結果を反映した「ほ場整備 事業等における水路整備の申し合わせ事項 (内規)」(以 下，「県内規」)が定められ, 現在に至っている. なお, 県 内規では，「ある程度の流れが常時ある水路については, 淀み, 深み, 泥溜めのうち, いずれかを設置することを原 則化」し，また「魚類の移動の妨げになる落差等を極力無 くすよう努めること」等を定めている.

なお, 石川県の自然環境にかかわる全体の主な施策と しては，2000年3月に石川県のレッドデータブック(以下 「RDB」) である「石川県の絶滅のおそれのある野生生物 (動物編, 植物編)」(石川県, 2000a；2000b)が作成されて いる. その後, 2009年に動物編の改訂版 (石川県, 2009), 2010年に植物編の改訂版 (石川県, 2010) が発行されて いる.また2004年3月に, 環境保全に関する基本的な条例 「ふるさと石川の環境を守り育てる条例」が制定され(石川 県, 2004b), 捕獲・採取の際には県の許可を必要とする 「石川県指定希少野生動植物種」が指定されている.また, 農林水産業に関しては, 環境への負荷低減のため「生態 系, 景観等との調和に配慮した生産基盤の整備を行うこと」
が明記されている.

2011年3月には「石川県生物多様性戦略ビジョン(以下 「県多様性ビジョン」)」(石川県, 2011) が策定され, トキが 舞う里山里海を未来の世代へ継承することを目標とした7 つの重点戦略の 1 つして，「流域全体における生態系保 全の視点にたった農地の整備を実施すること」が掲げられ ている. また, 2011年6月には能登半島が世界農業遺産に 認定されるなど,「里山里海の利用・保全に向けた一体的 な取り組み」が進められつつある。

\section{3 研究の方法}

本研究では, 石川県 (以下, 特に必要がない限り「県」と呼 称)におけるほ場整備に係わる事業(県営ほ場整備事業, 県営中山間総合整備事業, 農村活性化住環境整備事業) で, 県営ほ場整備事業が開始された1965年度から2012年 度までに着工された事業を対象とした。

まず, 対象とした全事業について, 環境配慮施設の設 置状況, 環境配慮対策工の種類, および保全対象種を明 らかにするために, 資料調査と聞き取り調査, 現地調査を 行った. 対象とするほ場整備事業については,「石川県の 土地改良」(石川県農林水産部, 1999；2003；2014）により 事業地区名と事業着工年度のリストアップを行い, 着工年 度を基準に年度別件数を集計した. 次に, 各事業におけ る環境配慮施設の設置の有無と設置年, 環境配慮対策工 法の種類について, 県農林水産部農業基盤課の内部資 料である「環境配慮施設状況一覧」(以下「県一覧表」) と, 県農業政策課技術管理室が管理する「環境配慮施設デ 一タベース」, 農地整備環境機能増進事業の報告書 (石 川県農林水産部農業基盤課・石川県土地改良事業団体 連合会, 2011)の資料で整理を行った. また，上記の3資 料で整合性のとれないデータについては現地調査, 担当 者への聞き取りにより一部修正を加えた。なお，配慮施設 の設置を伴わない生物の移植や濁水対策, 低騒音重機 の使用, 施工時期の調整等, 施工時における環境配慮に ついては，情報収集が困難であったため調査の対象外と した.

各事業における保全対象種については，上記「環境配 慮施設データベース」と, 各事業において新規事業採択 申請時に作成される環境配慮調書, さらに実施設計時に 専門的な環境調査を実施している場合は, その報告書を 元に種のリストアップを行った.

次に, 環境配慮施設の設置状況については, ほ場整備 事業に対する環境配慮施設の設置事業数を環境配慮施 設設置率として，3年間の期間毎に算出した。

環境配慮対策工の種類については, 国や県の環境配 慮に関する施策の転換期で3期に分け, 各期間別と対策 工の種類別に, 環境配慮を実施した事業件数に対する対 策工の実施割合を算出し, 環境配慮施設の設置方法の 変遷について分析を行った。

保全対象種については, 先に分けた 3 期間別に, 選定さ れた種ごとに選定事業数を集計し, 平均選定種数, 選定 事業数が上位の5種についての環境配慮事業数に対する 選定率, RDB掲載種の平均選定種数を算出し, 各期間の 保全対象種の選定傾向の特徵について分析を行った。

なお, 本文中において使用する「ビオトープ」の用語は, 農業農村整備事業において, 換地手法を活用して湿田な どを保全しビオトープ用地として創出する, 農業生産基盤 の機能を有さない池や湿地等を残置させるなどして, 生物 
生息空間として位置づけたものや整備をした空間の意味 で使用する.

\section{4 結果}

\section{1 石川県における環境配慮施設の設置状況}

対象期間内のほ場整備事業は合計165件であった. 初期 は事業件数も多くはなかったが, 担い手育成基盤整備事 業が創設された1993年度前後から10年間ほどは, 急増し た. その後は減少したものの, 近年はやや増加傾向にある (図 1).

165件のほ場整備事業のうち, 何らかの環境配慮施設 が設置された事業は71件で, 環境配慮施設設置事業率 (全ほ場整備事業に対する環境配慮施設設置事業の比 率) は, 国通達以後は直線的に増加し, 法改正時点では すでに $80 \%$ 前後, 2007 年度以降は $100 \%$ となっていた(図 1). なお国通達以前にも環境配慮施設の設置例があるが （1988年度事業着工）, これは事業着工年で集計している ためで, 実際の環境配慮施設の設置は1999年度である.

\section{2 石川県における環境配慮対策工法の変遷}

ほ場整備における生態系や生物多様性の保全上の問題 点は, 先述したように, 生物の生息場所の喪失・悪化と移 動経路の分断である. これらの問題への対策として石川県 で実施されてきた主な環境配慮対策工法の一覧を表 2 に 示した. これらの対策工法の採用状況を, 国通達後から県 指針以前 $(1991$ 年度～2003年度, 以下「国通達後」), 県 指針後から県パンフ以前 (2004年度〜2010年度, 以下「県 指針後」), 県パンフ以後 (2011年度〜2012年度, 以下「県 パンフ後」)の3期間に分けて表 3に整理した. 以下, 表 3 に従って, 対策工法の採用状況を施設ごとに説明する.

\subsection{1 ビオトープの設置}

これまでの環境配慮事業においてビオトープが設置され た事業件数は 30 件 $(42 \%)$ であった. ビオトープ設置の形 態は, 整備対象範囲内において換地を行い, 湿田など 元の環境をそのまま保全してビオトープ用地とする回避型

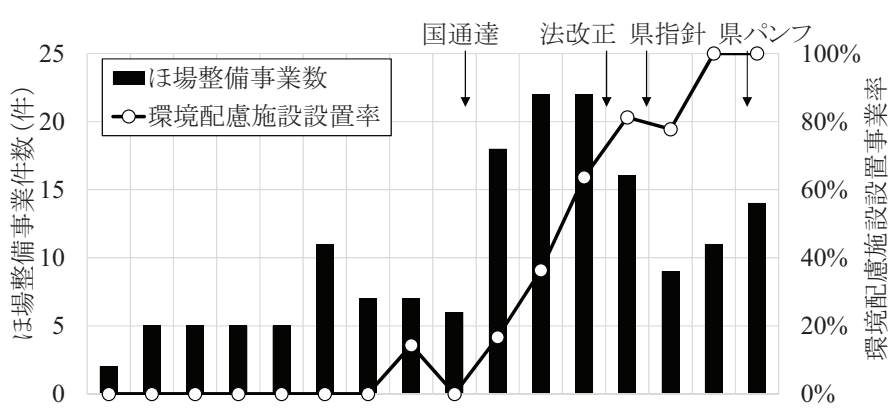

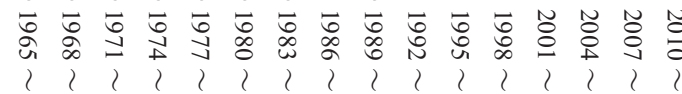

事業着工年度 $(\sim 3$ 年間 $)$

図 1: ほ場整備事業数と環境配慮施設設置事業率

表 2: ほ場整備よる生物多様性への影響と 環境配慮対策及び対策工法

\begin{tabular}{|c|c|c|c|}
\hline $\begin{array}{c}\text { 生物多様性 } \\
\text { への影響 }\end{array}$ & $\begin{array}{l}\text { 環境配慮 } \\
\text { 対策 }\end{array}$ & & 対策工法 \\
\hline \multirow{5}{*}{$\begin{array}{l}\text { 生息場所の } \\
\text { 喪失·憲化 }\end{array}$} & $\begin{array}{c}\text { ビオトープ } \\
\text { の設置 } \\
\end{array}$ & \multicolumn{2}{|c|}{ 回避型, 新設型 } \\
\hline & \multirow{4}{*}{$\begin{array}{l}\text { 調整池, } \\
\text { 水路への } \\
\quad \text { 配慮 }\end{array}$} & 調整池 & 土羽, 石積夕, 緩傾斜 \\
\hline & & $\begin{array}{l}\text { 水路護 } \\
\text { 岸 }\end{array}$ & $\begin{array}{l}\text { 木柵, 石積み, 蛇かご, } \\
\text { 魚巣ブロック }\end{array}$ \\
\hline & & 水路床 & $\begin{array}{l}\text { 底土, 穴あき水路, 深 } \\
\text { み工* }\end{array}$ \\
\hline & & 水路幅 & 淀み工** \\
\hline \multirow{2}{*}{$\begin{array}{c}\text { 移動経路の } \\
\text { 分断 }\end{array}$} & \multirow{2}{*}{$\begin{array}{c}\text { 移動経路 } \\
\text { の回復 }\end{array}$} & \multicolumn{2}{|l|}{ 魚道 } \\
\hline & & \multicolumn{2}{|c|}{ 脱出スロープ, エコブリッジ } \\
\hline
\end{tabular}

* 深み工: 水路底のみを下げる

**淀み工:深みに加え, 水路幅を広げる

表 3: 環境配慮対策工の採用状況

\begin{tabular}{|c|c|c|c|c|c|c|c|c|c|c|}
\hline \multirow{3}{*}{$\begin{array}{l}\text { 事業着工 } \\
\text { 年度期間 }\end{array}$} & \multirow{3}{*}{$\begin{array}{l}\text { 環境配慮 } \\
\text { 事業件数 }\end{array}$} & \multicolumn{8}{|c|}{ 環境配慮対策工の種類 } & \multirow{3}{*}{$\begin{array}{l}\text { 環境配慮 } \\
\text { 対策工の } \\
\text { 種類数の } \\
\text { 平均** }\end{array}$} \\
\hline & & \multirow{2}{*}{$\begin{array}{l}\text { ビオトー } \\
\text { プの設置 }\end{array}$} & \multicolumn{4}{|c|}{ 調整池, 水路への配慮 } & \multicolumn{3}{|c|}{ 移動経路の回復 } & \\
\hline & & & 調整池 & 水路護岸 & 水路床 & 水路幅 & 魚道 & $\begin{array}{l}\text { 脱出ス } \\
\text { ロープ }\end{array}$ & $\begin{array}{l}\text { エコブ } \\
\text { リッジ }\end{array}$ & \\
\hline $\begin{array}{c}\text { 国通達後 } \\
(1991 ２ 003)\end{array}$ & $39 *$ & $10(26)$ & $11^{*}$ & $17(44)$ & $3(8)$ & $2(5)$ & $10(26)$ & $6(15)$ & 0 & 1.5 \\
\hline $\begin{array}{c}\text { 県指針後 } \\
(2004 ２ 010)\end{array}$ & 22 & $13(59)$ & 1 & $7(32)$ & $10(45)$ & $11(50)$ & $6(27)$ & $9(41)$ & $4(18)$ & 2.8 \\
\hline $\begin{array}{c}\text { 県パンフ後 } \\
(2011 〜 2012)\end{array}$ & 10 & $7(70)$ & 0 & 0 & $8(80)$ & $6(60)$ & $2(20)$ & $6(60)$ & $2(20)$ & 3.1 \\
\hline 全 体 & $71 *$ & $30(42)$ & $12 *$ & $24(34)$ & $21(30)$ & $19(27)$ & $18(25)$ & $21(30)$ & $6(8)$ & 2.1 \\
\hline
\end{tabular}

数字：事業件数，（）内：環境配慮事業件数に対する割合 $(\%)$

* : 1988 年度事業着工・1999 年度環境配慮施設設置の 1 事業も含む

** : 環境配慮対策工の種類数の平均は, 環境配慮対策工種類数合計／環境配慮事業件数とした 
と, 用地を確保し新たに生息空間を作る新設型があり, 回 避型は22件, 新設型は5件で, 両方を併せ持つ複合型は3 件であった. 設置率の変化をみると, 国通達後は $26 \%$ にと どまっていたが, その後急増し, 県パンフ後は70\%に達し ていた.

詳細図面情報が得られた25件のビオトープの平均面積 は $740 \mathrm{~m}^{2}$, 総受益面積に対する比率は平均 $0.21 \%$ であつ た.

\subsection{2 調整池, 水路への配慮}

ほ場整備に伴って農業用水路のパイプライン化が進めら れ, その付帯施設として調整池(ファームポンド)が新たに 設置される場合が多く, 国通達後は環境配慮が実施され た事業では39件のうち37件で(1988年度事業着工, 1999 年度環境配慮施設設置の1件も含む), 県指針後は22件 のうち17件, 県パンフ後は全事業で調整池が設置されて いた。 その調整池に対して, 石川県においては, コンクリ 一トやマットで護岸せず, 石積みや土羽としたり, さらに緩 傾斜とするなど, 水際の生物の生息空間の創出に配慮し た対策が，国通達後は30\%(37件中11件)で実施されてい た.しかし，県指針後は6\%(17件中1件)のみで, 県パンフ 後になると全く実施されなくなっていた。

水路護岸への環境配慮対策としては, 部分的にコンクリ 一下護岸を回避して石積みや木柵, 蛇かご等による護岸と することや, コンクリート二次製品の魚巣ブロックを使用す る配慮がなされていた. 水路床については, フリューム で施工した一部の区間を土水路のままで残して（底土） 水生生物の生息環境の改変を回避したり, 穴のあいたフリ ユーム(穴あき水路)を使用して地下水涵養を促す例があ った. またフリューム水路の一部の区間について水路底を 下げて設置し(深み工), 流量が少ない時にも水生生物が 生息できる場所を設置していた。 また, 流速の多様性を確 保するために水路底に深みを作った上で水路幅を広げる 淀み工が設置されていた。

これらの対策工法の設置事業率の変化をみると(表 3)， 水路護岸への対策は, 国通達後は44\%であったが, その 後は減少し，県パンフ後はまったく実施されていなかった。 それに対して, 水路床と水路幅への対策は, 国通達後は ごく低い比率であったが，県指針後はいずれも急増し，県 パンフ後はそれぞれ $80 \%, 60 \%$ に達していた。これは県パ ンフで大きく取り上げられた深み工や淀み工の設置事業 率が，国通達後はそれぞれ3\%，6\%であつたものが，県パ ンフ後には $70 \%, 60 \%$ と急激に増加したことを反映したもの であった。

\subsection{3 移動経路の回復}

動物の移動経路を回復させる対策として, 魚道, 脱出スロ ープ, エコブリッジが設置されていた。

魚道は, 水路内の落差工に設置したものと, 排水路と水 田の落差に設置したもの, ビオトープと周辺水路とをつな ぐものの3種類であった. 設置事業数は合計 18 件 $(25 \%)$ で， 県パンフ後にも目立った増加は見られなかった。

陸域または, 陸域と水域との分断点については, 脱出ス ロープ, エコブリッジなどの対策が施工されていた. 脱出ス ロープは, 小動物が水路に落下した際に這い上がるため の施設で, ベンチフリュームに幅 $10 〜 20 \mathrm{~cm}$ 程度のコンクリ 一トスロープを水路縦断方向に這わせたものが多かった。 設置事業数は合計 21 件 $(30 \%)$ と, 全期間を通じて魚道と
同程度であるが, 国通達後は15\%の設置事業率であった ものが, 県指針後は41\%, 県パンフ後は60\%と急増してい た.

エコブリッジは, 小動物がほ場と周辺樹林地とを行き来 するための施設で, コンクリート水路の横断方向に幅30〜 $100 \mathrm{~cm}$ 程度の木製またはコンクリートの橋をかけたものであ った.この工法は県指針後から設置されはじめたが, 設置 事業数は合計6件 $(8 \%)$ で, 県パンフ前後で設置事業率に 大きな変化はなかった。

\subsection{4 対策工法の組み合わせ}

環境配慮工事が実施された事業において, 1事業で実施 された対策工法の種類数の平均は, 国通達後が 1.5 種類, 県指針後が 2.8 種類, 県パンフ後は3.1種類と着実に増加 していた.

環境配慮対策の効果をより発揮させるには, 対策工法 の適切な組み合わせを行うことが重要である. そこで, 1 事 業の中で対策工法がどのような組み合わせで実施されて いたかを表 4にまとめた. 魚道に水路護岸対策, 水路床, 水路幅の工法を組み合わせて設置している割合は，国通 達後は60\%(10件中6件)であつたものが，県指針後は $83 \%$ (6件中5件), 県パンフ後は100\%と増加していた. また脱 出スロープに水路床や水路幅の工法を併せて設置してい る割合も，国通達後が17\% (6件中1件)，県指針後は67\% (9件中6件), 県パンフ後は100\%と増加していた。

表 4: 対策工法の組み合わせ

\begin{tabular}{c|cc|cc}
\hline $\begin{array}{c}\text { 事業着工 } \\
\text { 年度期間 }\end{array}$ & $\begin{array}{c}\text { 魚道 } \\
\text { のみ }\end{array}$ & $\begin{array}{c}\text { 魚道十護 } \\
\text { 岸対策等 }\end{array}$ & $\begin{array}{c}\text { 脱出スロ } \\
\text { ープのみ }\end{array}$ & $\begin{array}{c}\text { 脱出スロープ } \\
+ \text { 水路床対策 } \\
\text { 等 }\end{array}$ \\
\hline 国通達後 & 4 & $6(60)$ & 5 & $1(17)$ \\
県指針後 & 1 & $5(83)$ & 3 & $6(67)$ \\
県パンフ後 & 0 & $2(100)$ & 0 & $6(100)$ \\
\hline
\end{tabular}

（ ）内:期間中の対策工法を組み合わせた割合

\subsection{5 水路の環境配慮対策工の素材}

水路の環境配慮対策工の材料を自然素材とコンクリート製 品に分類し，その割合の変化を表 5に示した。ここで自然 素材としたものは, 石, 木, 土などを使用している石積み, 木柵, 蛇籠, 底土が該当する. 魚巣ブロック, 穴あき水路, 深み工, 脱出スロープは, コンクリート製品による対策工事 として分類した. なお, 水路内に設置されている魚道, エコ ブリッジは, 県内ではどちらの素材も使用されているため 集計から除外した。

国通達後に, 護岸, 水路床, 水路幅への対策を実施し た 20 事業中, 自然素材の夕を使った事業が10件, 両方が 3件で，合わせて 13 件 $(65 \%)$ で自然素材が使用されてい たが，その後は減少し，県パンフ後は9事業中3件 $(33 \%)$ になっていた. 逆に, コンクリート製品の使用は, 国通達後 は20事業中 10 件 $(50 \%)$ であったが, 県パンフ後は9事業 中8件 $(89 \%)$ にまで増加していた(表 5).

\section{5 保全対象種}

環境配慮が実施された全事業で選定された保全対象種 は69種であった（表 6). 内訳を見ると，一番多く選定され た種はドジョウで 27 件, 次いでメダカの 15 件, 二ホンアカガ 
表 5: 水路内の対策工の素材

\begin{tabular}{c|c|ccc}
\hline $\begin{array}{c}\text { 事業着工 } \\
\text { 年度期間 }\end{array}$ & $\begin{array}{c}\text { 水路内の } \\
\text { 環境配慮 } \\
\text { 事業件数 }\end{array}$ & $\begin{array}{c}\text { 自然素材 } \\
\text { のみ }\end{array}$ & $\begin{array}{c}\text { コンクリート } \\
\text { 製品のみ }\end{array}$ & 両方 \\
\hline 国通達後 & 20 & $10(50)$ & $7(35)$ & $3(15)$ \\
県指針後 & 16 & $1(6)$ & $8(50)$ & $7(44)$ \\
県パンフ後 & 9 & $1(11)$ & $6(67)$ & $2(22)$ \\
\hline
\end{tabular}

（ ）内:期間中の対策工の素材割合

エル14件, トノサマガエル13件であった. カエル類としては， 他にツチガエルやヤマアカガエル，モリアオガエルが一部 の事業で選定されており, 単にカエルとした事業もあり, す べてをまとめてカエル類としてみると23の事業で選定され ていた. また, ホタル類は, ゲンジボタルが7件, へイケボタ ルが 2 件 (らちゲンジボタルとへイケボタルの両方が 1 件), 単にホタルとした事業が7件, 全体として15件であった。

環境配慮が実施された71事業のうち, 保全対象種選定 に関する情報が不明な5件を除く66事業について, 保全対 象種の選定状況について分析した. 66事業のうち保全対 象種を指定していない事業は16件で，いずれも2002年の 改正法施行前の事業であった. 各事業で選定された保全 対象種の平均種数を, 表 3 と同様に3期間に分けてみると, 国通達後は0.9種であったが, 県指針後は3.9種, 県パンフ

後は6.5種と急激に増加する傾向にあった(表 7).

各期間の上位 5 種 (カエル類, ホタル類はそれぞれまと めて1種とする)について, 選定された事業の比率 (選定事 業率)をみると(図 2), 国通達後は, 1位のホタルでも $18 \%$ の事業で選定されているに過ぎず, 事業ごとに異なった種 類が選ばれる傾向にあった. それに対し, 県パンフ後は, 1位のカエル類が $90 \%, 2$ 位のドジョウが $70 \%$, 大半の事 業でカエル類とドジョウが選定されており, 特定種に集中 する傾向が顕著であった.

一方で, 生態系の上位種である猛禽類は, 国通達後は まったく選定されていなかったが, 県パンフ後は4種が選 定されていた. 植物は, 国通達後の選定は0種であったが, 県指針後は4種, 県パンフ後は7種と増加する傾向にあっ た. 選定された植物の多くや猛禽類は石川県のRDB掲載 種であり, それを反映して, 保全対象種における石川県の レッドデータブック掲載種の1事業あたり選定種数は, 国通 達後の事業では平均 0.1 , 県指針後は 0.2 , 県パンフ後は 1.5と急増していた（表 7).

上に見たように, 県パンフ後は保全対象種の選定種数 は増加し, 希少種の選定種数も増加していたが, しかし一 方で, どの事業でも同じような種 (ドジョウとカエル類)を選 定する傾向が強まった。

なお, 選定種を種名ではなく, カエル, ホタル, トンボな どといった一般名称であげる割合は, 国通達後は選定さ れた保全対象種の34\%, 県指針後は22\%であつたが, 県 パンフ後は2\%と激減し, より正確な種として選定されること が多くなる傾向があった。
表 6: 保全対象種

\begin{tabular}{|c|c|}
\hline 分類群 & 保全対象種 \\
\hline $\begin{array}{l}\text { 植物 } \\
10 \text { 種 }\end{array}$ & 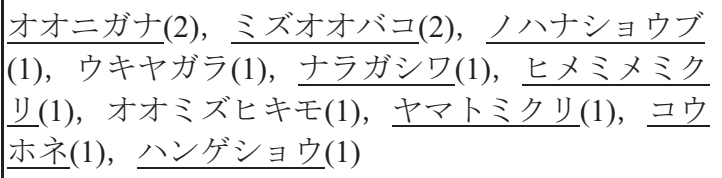 \\
\hline $\begin{array}{l}\text { 鳥類 } \\
7 \text { 種 } \\
\end{array}$ & $\begin{array}{l}\text { オオヒシクイ(1)， チュウサギ(1)，分クマ(1)，ミ } \\
\text { サゴ(1)， サシバ(1)，乔ュウヒ(1)，サギ(3) }\end{array}$ \\
\hline $\begin{array}{c}\text { 両生・は } \\
\text { 虫類 } \\
11 \text { 種 }\end{array}$ & $\begin{array}{l}\text { ニホンアカガエル(14), トノサマガエル(13), ヤマ } \\
\text { アカガエル(2), ツチガエル(2), モリアオガエル(1), } \\
\text { ホクリクサンショウウオ(1), アカガエル(1), カエ } \\
\text { ル(4), イモリ(3), ヘビ(1), カメ(1) }\end{array}$ \\
\hline $\begin{array}{l}\text { 魚類 } \\
23 \text { 種 }\end{array}$ & $\begin{array}{l}\text { ドジョウ(27), メダカ(15), タモロコ(6), ギンブナ } \\
(5), \text { ホトケドジョウ(4), ナマズ(3), ヤリタナゴ(2), } \\
\text { スナヤツメ(2), ドンコ(2), アユ(2), アブラハヤ(2), } \\
\text { ウグイ(2), ウキゴリ(2), トミヨ(1), シマドジョウ } \\
(1), \text { ジュズカケハゼ(1), カジカ(1), サクラマス(1), } \\
\text { コイ(1), フナ(2), ヨシノボリ(1), タナゴ(1), ハゼ } \\
\text { (1) }\end{array}$ \\
\hline $\begin{array}{c}\text { 昆虫類 } \\
12 \text { 種 }\end{array}$ & $\begin{array}{l}\text { ゲンジボタル(7), ゲンゴロウ類(3), オオコオイムシ } \\
\text { (3), ゲンゴロウ(2), コオイムシ(1), タイコウチ(1), } \\
\text { オニヤンマ(1), ハグロトンボ(1), ヘイケボタル(2), } \\
\text { ホタル(7), トンボ(4), ヤゴ(2) }\end{array}$ \\
\hline $\begin{array}{r}\text { 貝類 } \\
6 \text { 種 } \\
\end{array}$ & $\begin{array}{l}\text { カワニナ(4), マルタニシ(2), イシガイ類(2), マ } 1 \text { マツ } \\
\text { カサガイ(1), ドブガイ(1), タニシ(2) }\end{array}$ \\
\hline
\end{tabular}

下線 : 石川県 RDB 掲載種（石川県, 2009; 2010）

（）: 選定した事業件数

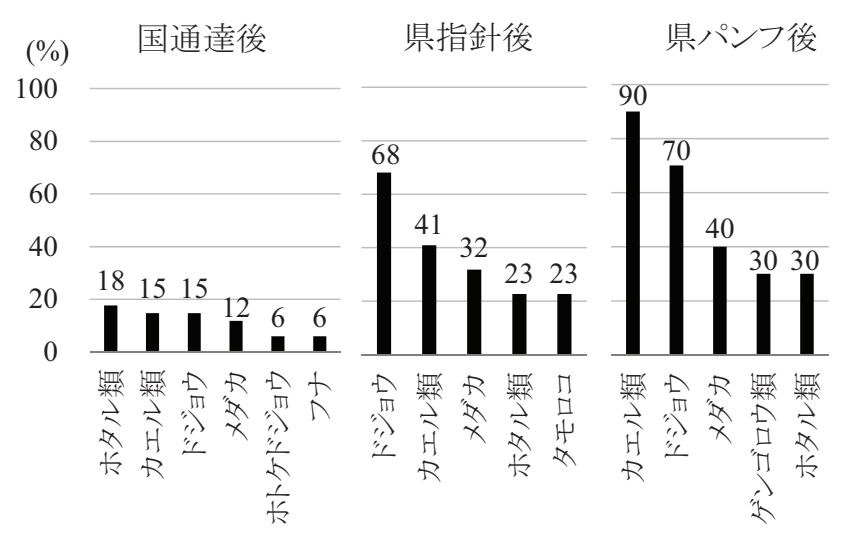

図 2: 保全対象種上位 5 種の選定事業率

表 7: 1事業で保全対象種に選定された種数

\begin{tabular}{c|c|ccc|c}
\hline \multirow{2}{*}{$\begin{array}{c}\text { 事業着工 } \\
\text { 年度期間 }\end{array}$} & \multirow{2}{*}{$\begin{array}{c}\text { 保全対象種 } \\
\text { 選定 }\end{array}$} & \multicolumn{4}{|c}{ 保全対象種の種数 } \\
\cline { 3 - 6 } & 件数 & 平均 & 最大 & 最小 & $\begin{array}{c}\text { 石川 } \\
\text { RDB } \\
\text { 掲載種 }\end{array}$ \\
\hline 国通達後 & 34 & 0.9 & 4 & 0 & 0.1 \\
県指針後 & 22 & 3.9 & 9 & 1 & 0.2 \\
県パンフ後 & 10 & 6.5 & 10 & 4 & 1.5 \\
\hline
\end{tabular}




\section{6 考察}

石川県のほ場整備における環境配慮は，1991年の国通 達直後より開始され，2001年の法改正時にはすでに $80 \%$ の実施率に達し, 近年は $100 \%$ の事業で実施されているこ とが明らかになった.この比率が他の都道府県と比べて高 い值かどうかは, 残念ながら今回は明らかにできなかった が，2013年時点で,「国営事業に比べて県営, 市町村営 事業では, 短期間, 低予算といら制限のため環境配慮の 取り組み事例が少ない傾向が見られる」との指摘(社団法 人地域環境資源センター, 2013) があることから, 決して低 い比率でないことは確かである. また, 農業農村整備事業 に特化した環境配慮指針が，新潟県を含む北陸4県では， 石川県以外に未だに制定されていない(各県担当者への 問い合わせによる)のに対し, 石川県では改正法施行 2 年 後の2004年といら早い時点で制定されたこと, 指針副読本, 参考事例集を合わせた大部の冊子として作成されている こと, さらに, それから5年後に環境配慮事業の見直しのた めに増進事業を実施し, 農家や地域住民にもわかりやす い形で環境配慮の意義や留意点をまとめた県パンフを発 行したこと等を合わせて考えると, 石川県では当初から環 境配慮への取り組み意識が比較的高かったと言えよう.

先述したように, 県指針には地域住民と一体となった取 り組みとするための副読本も添付されており, それによって 地域住民の環境配慮への理解も促進されたと考えられる. 県指針後に，住民に維持管理の負担が伴うビオトープ造 成が急増する傾向にあつたこと，事業当たり環境配慮工の 種数が増加したこと, 1 事業の保全対象種数が増加したこ となどは，それを反映したものと思われる. 保全対象種の 増加には, 協議会委員も交えた生物調査やコンサルタント 業者による生物調査が実施されるようになったことも大きく 影響していると思われる. それによって地域に生息する希 少種の存在が明らかになり, 特に植物や猛禽類などの希 少種を選定することが多くなったと考えられる.ただ，一般 には, 保全対象種に選定された植物への対応は移植, 猛 禽類への対応は繁殖期をさけた施工時期の設定といった 環境配慮が主であり, 必ずしも保全対象種の増加ほじに は環境配慮対策工設置の大きな増加にはつながらない.

石川県における環境配慮の方向性を大きく変えたと思 われるのは, 2011年策定の県多様性ビジョンである. その 中で目標とされたトキが舞う環境を実現するために, 増進 事業の検討結果を受けて同年に作成された県パンフにお いても, 今後のほ場整備ではトキの餌生物であるドジョウ やカエル類に配慮した事業としていくことが明記されてい る. 県パンフ発行後に, 保全対象種として挙げられる生物 種において, ドジョウとカエル類が著しく増加していたこと や, 県内規において, 水路における水路床対策 (深み工, 泥溜め) や拡幅対策 (淀み工)の対策工法のいずれかを設 置することと規定され, 実際に設置数が急増したことも, ド ジョウやカエル類の保全を強く反映した結果と考えられる.

このように石川県における環境配慮事業は, 国の動向 を敏感に反映させ，比較的早くから開始されていた県独自 の取り組みもあって量的には充実したものとなり, さらには， 県多様性ビジョンによって, トキを舞わせるといら目標が明 確化されたことで, 環境配慮の質的内容もそれに応じて変 化してきたと考えられる.

石川県における最近の傾向として, 水路の対策工にお いて自然素材の利用が減少し, コンクリート製品が多用さ れる傾向にあることが明らかになった. コンクリート製品は,
その耐用性の高さやコストの低さもあるが，何よりも維持管 理が比較的容易であるため選択されているものと思われる。 しかし, コンクリート製品の多用化は, 国手引きで周辺環境 との調和, 工事費の面から, 水路の施工においては地域 で採取できる自然材料の使用が望ましいとしていることや， コンクリート製品の使用は配慮のレベルとしては低く位置 づけられていること, また県指針で, 管理労力や利便性を 考慮しつつも, 「地域産材 (間伐材, 地場材料) や伝統的 技術の活用すること」とされていることと逆行するものであ る.

環境配慮施設の設置後の維持管理は, 全国の多くの地 区で直面している問題であり, 維持管理を担う地域住民一 の配慮から, 環境配慮レベルが低いコンクリート製品が多 用される傾向があるように思われる. 社団法人地域環境資 源センター(2013) は, それまで全国各地で行われてきた 環境配慮事業を総括し, 環境配慮施設の維持管理や利 用が問題となって地域の合意形成や組織形成に至らなか ったことや, 環境配慮型施設の導入時に「コンクリート施工 にしないと従前よりも維持管理労力が減少しない」といら住 民の思いがあることを指摘している。

石川県の場合は, それに加えて, トキをシンボルとした 県多様性ビジョンを打ち出しているという特有の事情が, コ ンクリート製品の多用化と関連している可能性がある. すな わち, 先述したように, 県パンフ後にトキの主要な慨生物 であるドジョウとカエル類を保全対象種にあげる地区が急 増しているが, これらの生物は, 環境配慮工法において, 深み, 淀み, 泥溜め, 脱出スロープやエコブリッジといった コンクリート製品でも，ある程度対応できる生物であるため， そのことがコンクリート製品の多用化を許容することに繋が っている可能性がある.

かつて, ホタル一辺倒の保護活動の弊害が指摘された ことがあるが，ごく一部の特定生物への保全活動の集中は， かえつて生物多様性の保全を阻害する危険性がある.ここ で問題としている, 淀み, 深み, 泥溜めを設置する目的は, 本来, 国手引きや県パンフにあるように「多様な水深, 流 速, 瀬や淵の確保」にあり, 多様な生物のそれぞれの発育 段階における多様な生活要求への配慮を目的としたもの である. コンクリート製品という単純化された環境配慮施設 で，それが十分に達成されるかは疑問と言わざるを得ない であろう.また，どの地域でも同じような保全対象種が設定 され, コンクリート製品による同じような環境配慮施設が設 置されることは, 生物の生息空間の均一化・単純化をもた らし, 地域の独自性の消失と広域的な生物多様性の低下 を招く危険性がある. また, 護岸対策でもある脱出スロー プが増えることで他の護岸対策が減少する傾向があったこ とは, 特定の生物への配慮に焦点が当てられすぎることで, 他の生物への配慮が低下する可能性もあるということをこ の例は示しているように思われる.

では，環境配慮と維持管理に関するジレンマについて は, どのような解決策が考えられるであろうか. 環境配慮の 計画において考慮すべき点として, 国手引き1(農林水産 省農村振興局計画部事業計画課, 2004aのp.58)では, 生 物の生息・生育条件の確保と経済性や維持管理作業性の バランスを考慮して設計を行うことが重要であるとし,レー ダーチャートを使って検討する例が示されている. 実際, 県指針においても，環境配慮による工事費・維持管理費， そして保全効果 (可能性)を複数の工法について比較する 資料を作成して地元説明を行うよう求めている. 工事費を 
負担し, 将来の維持管理を主に担う地域住民の意向を把 握する手続きを示した点で, きわめて重要な指針であると 思われる. しかし，この手続きにおいて問題となるのは, バ ランスを考える上で取り上げられている工費や維持管理費, そして維持管理性や生態系保全などの要因における単位 が等価ではないため, レーダーチャートで一見バランスが とられているように見えても，それを鵜吞みにはできないと いら点である. 特に生態系保全の効果については, 生物 多様性の保全といら観点だけではなく, 住民にとつての生 物多様性の価值をも考慮するから゙うかによって, その評価 は大きく変わりうるため, 環境配慮事業のバランスも大きく 変化する可能性がある.

後者の観点が問題になるのは, 農業農村整備事業にお ける保全対象種の選定においては, 通常の環境アセスメ ントにおける選定基準 (上位性, 典型性, 特殊性, 希少性) に加えて, 地域との関係性といら基準があるからである. 国 手引き1では「生態系の観点から検討することはもとより, 農村の生態系の特徵を踏まえ, 農家を含む地域住民の意 識, 歴史文化の継続性, 営農との関わりの視点からも検討 を行う」としている. 国指針ではもう少し具体的に,「地域住 民の興味や関心も高いと考えられる地域住民と関わりの深 い生物を選定することも考えられる」としている. そして, 環 境配慮に対する住民の理解や協力を得やすくなるとして, 例えば「アキアカネがたくさんいる環境を残したい」といっ た住民の意向が選定の視点となるとしている.このような視 点は，人間との相互作用の結果成立している二次的自然 環境に成立した「二次的生物多様性」(上田, 2012)の保 全を考える上で, きわめて重要な視点であると思われる.

嘉田 (2002) は, 生物には物質価值, 生命価值, 交感価 值の3つの価值があるとし, 生命価值や交感価值について は主観によって大きく変わると考えられるとしている.つまり, 生物の価值はアプリオリに決まるものではなく, 人々の関 心の在り方, 主観の在り方によって変化するということであ る. そうであるならば，地域住民が生物の持つ価值を高く 評価すれば, 生態系保全の価值は高く評価され, 維持管 理の労力やコストの負担感は相対的に低下し, 結果的に 高いレベルの環境配慮が実現する可能性もあると考えら れる. さらには, 維持管理を負担としてとらえる考え方から 脱却し，むしろ維持管理作業を生物と触れ合う機会, 地域 住民同士が交流する機会としてとらえる積極的な取り組み に発展する可能性もあるといらことである。

では，地域住民の身近な生物への評価を高めるために はどのような取り組みが考えられるだろうか. 何よりも身近 な生物への関心を回復させることが必要であるが, このこと と関連して石川県において注目される点がある。それは, 県指針の中で,「改正法による方向転換を機に, ほ場整備 事業の調査時の生きもの調査を, ほ場整備事業の意義と 自然環境の重要性を子どもたち, さらには非農家住民に 教える環境教育の場とする」といら積極的な観点が強く示 されていることである. 石川県では, 法改正前から生態系 保全に関する種々の取り組みがあり, 中でも環境教育との 連携した取り組みが見られたことを先に指摘したが，その ような取り組みを今後も意識的に発展させていくことで, 子 どもたちや大人が地域の自然や生物に関心を持つように なり，身近な自然環境の大切さを理解する機会を提供し， 郷土愛を育むことにも貢献できる事業として展開できる可 能性がある。

さらに, 今後, このような取り組みを環境配慮の計画に
先だって実施することで, 地域の生物への地域住民の理 解が進み, 住民主体の保全対象種の選定が行われるよう になれば, どの地域でも同じ生物が保全対象種に選定さ れるといった弊害を抑制することにつながると考えられる. また，すでに環境配慮施設が設置されている地域におい ても, 住民主体のモニタリング調査と順応的管理が実施さ れることが進めば, 新たな保全対象種を地域住民が設定 することも可能である. その結果, 特定生物に保全が集中 している現在の課題への解決にも結びつくと考えられる.

環境配慮施設を, 維持管理の負担感ばかりが感じられ る地域の「お荷物」から地域の「お宝」へと変化させるため の取り組みについて, 今後は検討を進めていくことが重要 であると思われる.

\section{7 まとめ}

石川県を事例として, ほ場整備事業における環境配慮へ の取り組みの経緯と変遷を整理・分析したところ, 次に示 すことが明らかとなった. (1)環境配慮施設の設置は1991 年の国通達直後より開始され，(2)2001年の土地改良法改 正時にはすでに $80 \%$ の実施率に達し, 近年は $100 \%$ の事 業で実施されていることが明らかになった. そして, (3)各事 業での環境配慮対策工法の種類や保全対象種の選定種 の数も増加傾向にあった. (4)その一方で, ドジョウとカエル 類がほとんどの事業で保全対象種に選定されていた. (5) 環境配慮工へのコンクリート製品の多用が目立つようにな っていた.このような傾向は, 地域住民の維持管理の負担 軽減を図ることに加え, 特定の種に保全目標が集中したこ とが影響していると推察された. 今後, 生物多様性を保全 するための, より効果的な環境配慮施設を実現するために は, 環境教育と連携しながら地域住民の生き物に対する 意識を変える必要があると考えられた。

\section{謝辞}

本研究を遂行するにあたつて, 石川県農林水産部農業基 盤課，農業政策課技術管理室，各農林総合事務所の皆 様方に, また石川県土地改良事業団体連合会の石黒徳 広氏に, 環境配慮に関する情報の収集, ご提供を頂き, 聞き取り調査に際しても多大なご協力を頂いた. また，農 林水産省農村振興局には国の施策等についての情報を ご提供頂いた.ここに謹んでお礼申し上げる.

\section{引用文献}

１1］江崎保男-田中哲夫 (1998): 水辺環境の保全一生物群 集の視点から一, 朝倉書店, $220 \mathrm{p}$.

[2] 石川県 (2000a): 石川県の絶滅のおそれのある野生生物 〈動物編〉, 石川県環境安全部自然保護課, $155 \mathrm{p}$.

[3] 石川県 (2000b): 石川県の絶滅のおそれのある野生生物 〈植物編〉, 石川県環境安全部自然保護課, 358 p.

[4] 石川県 (2004a): :しかわほ場整備環境配慮指針・指針 副読本・参考事例集, 石川県農林水産部, 268 p.

[5] 石川県 (2004b)：ふるさと石川の環境を守り育てる条例, 石川県環境部環境政策課, 2013.11.22.

http://www.pref.ishikawa.lg.jp/kankyo/jyorei/list.html (201 4年7月7日アクセス).

[6] 石川県 (2009) : 改訂・石川県の絶滅のおそれのある野生 生物-いしかわレッドデータブック〈動物編〉2009, 石川県 環境部自然保護課, 2014.3.17.

http://www.pref.ishikawa.lg.jp/sizen/reddata/rdb_2009/ind 
ex.html(2014年7月7日アクセス), 446p.

[7] 石川県 (2010) : 改訂・石川県の絶滅のおそれのある野生 生物-いしかわレッドデータブック〈植物編〉2010, 石川県 環境部自然保護課, 2014.3.17.

http://www.pref.ishikawa.lg.jp/sizen/reddata/rdb_2010/ind ex.html(2014年7月7日アクセス), 761p.

[8] 石川県 (2011): 石川県生物多様性戦略ビジョン一トキが 羽ばたくいしかわを目指して一, 石川県環境部里山創成 室, 2011.3.

http://www.pref.ishikawa.lg.jp/ontai/vision/documents/ishi kawa_biodiversity_vision_all.pdf(2014年7月7日アクセス)， $101 \mathrm{p}$.

[9] 石川県環境安全部 (2001): 広げよう！小さないしかわ動 物園づくりーいしかわビオトープ推進マニュアル, 石川県 環境安全部自然保護課, p.1.

[10] 石川県農林水産部 (1999) : 石川県の土地改良 (平成9年 度版), 石川県農林水産部経営対策課, pp.86-354.

[11] 石川県農林水産部 (2003): 石川県の土地改良 (平成13 年度版), 石川県農林水産部経営対策課, pp.126-361。

[12] 石川県農林水産部 (2014): 石川県の土地改良 (平成24 年度版), 石川県農林水産部経営対策課, pp.79-124.

[13] 石川県農林水産部農業基盤課 (2011)：いしかわのほ場 整備における環境配慮の取り組み (パンフレット), 石川県 農林水産部農業基盤課農地整備グループ, 22 .

[14] 石川県農林水産部農業基盤課・石川県土地改良事業団 体連合会 (2011): 平成22年度農地整備環境機能増進事 業 (事後効果検証型) 生態系配慮施設調査業務報告書.

[15] 岩村和平(2001)：農業農村整備事業における環境保全 対策の状況, 農土誌, 69(9), pp.941-944.

[16] 嘉田由紀子 (2002) : 自然と生活の距離, 科学, 72(1), pp.34-44.

[17] 水谷正一 (2007) : 農村の生き物を大切にする水田生態工 学入門, 社団法人農山漁村文化協会, 204 p.
[18］森淳・水谷正一・高橋順二 (2008) : 水田生態系の特徵と 変質一水田生態工学の視点加一, 農業農村工学会論 文集, 254, pp.211-221.

[19] 中川昭一郎 (2000) : 圃場整備と生態系保全「農村ビオ卜 ープ」, 信山社サイテック, pp.70-81.

[20] 中川昭一郎 (2001): 農業農村整備とビオトープの保全・ 創出, 農土誌, 69(9), pp.927-931.

[21] 農林水産省農村振興局計画部事業計画課(2004a)：環 境との調和に配慮した事業実施のための調査計画・設計 の手引き 1 一基本的な考え方・水路整備一, 社団法人農 業土木学会, $182 \mathrm{p}$.

[22] 農林水産省農村振興局計画部事業計画課(2004b) : 環 境との調和に配慮した事業実施のための調査計画・設計 の手引き2一ため池整備 農道整備 移入種一, 社団法 人農業土木学会, $118 \mathrm{p}$.

[23］農林水産省農村振興局計画部事業計画課(2004c)：環 境との調和に配慮した事業実施のための調査計画・設計 の手引き3一ほ場整備 (水田・畑) 一, 社団法人農業土木 学会, $173 \mathrm{p}$.

[24] 農林水産省農村振興局計画部事業計画課 (2007) : 農業 農村整備事業における生態系配慮の技術指針, 社団法 人農業土木学会, $159 \mathrm{p}$.

[25] 奥池伸隆 (2002): 田んぼのまなび舎設置事業一ほ場整 備事業 福増・中屋地区での取り組み一, 圑場と土畩, 34(4), pp.2-6.

[26] 社団法人地域環境資源センター (2013) : 農業農村整備 事業における総合的な環境配慮ガイドライン, 134 p.

[27] 棚木環・生玉修一・高石洋行 (2004): 環境創造型事業一 の転換と課題. 圃場と土壤, 36(2), pp.3-9.

[28] 上田哲行 (2012): 流域で守る生物多様性, 石川県立大学 年報, 23, pp.1-6.

[29] 熟谷いづみ(2006): 地域と環境がよみがえる水田再生, 家の光協会, 293 p.

この論文の公開の質疑または討議は2015年12月31日 まで受付けます. 
